\title{
Mating patterns and pollen dispersal in a natural knobcone pine (Pinus attenuata Lemmon.) stand
}

\author{
JAROSŁAW BURCZYK*†, W. T. ADAMS $\$$ \& JARBAS Y. SHIMIZU§ \\ $\dagger$ †epartment of Genetics, Institute of Dendrology, Polish Academy of Sciences, PL 62-035 Kórnik, Poland, \\ $\ddagger$ Department of Forest Science, Oregon State University, Corvallis, OR 97331-5705, U.S.A. and §Centro Nacional de \\ Pesaquisa de Florestas (CNPF/EMBRAPA), Caixa Postal 319, Colombo (Guaraituba), Parana, Brazil 83411-000
}

\begin{abstract}
Mating system and effective pollen dispersal were studied in a natural stand of knobcone pine (Pinus attenuata Lemmon.) using 11 isozyme loci. Analyses were performed by fitting neighbourhood and mixed-mating models to multilocus genotypic arrays of offspring from four mother trees. Neighbourhoods consisted of all potential outcross males within $11 \mathrm{~m}$ of each mother tree (44, on average). Average outcrossing rates of the mother trees were estimated to be 0.97 and 0.96 for the respective models, whereas the population-wide outcrossing rate based on the mixed-mating model and a broader sample of mother trees was 0.92 . The estimated proportion of offspring sired by males outside the neighbourhood of each mother tree was 0.56 . Thus about 41 per cent of matings resulted from outcrossing with nearby males (within neighbourhoods). Distance and direction of individual males from mother trees and the size (tree height) of males played significant roles in determining outcross mating patterns within neighbourhoods. Male mating success increased with both proximity and tree size, although males east of mother trees accounted for more offspring than males in other directions. Despite the role of proximity, directionality and tree size in determining mating success within neighbourhoods, the effective number of males mating with each female seems to be large.
\end{abstract}

Keywords: gene flow, mating success, mating system, neighbourhood model, outcrossing, Pinus attenuata.

\section{Introduction}

Mating systems and patterns of pollen dispersal play a central role in plant population genetics (Levin \& Kerster, 1974; Hamrick, 1989). They influence effective population size and the degree of population subdivision resulting either from drift or differential selection. In addition, they affect levels of inbreeding and genetic structure within populations. Knowledge of mating systems and gene flow is also important for managing breeding populations (Levin \& Kerster, 1974; Adams \& Birkes, 1991) and for designing efficient genetic conservation strategies (Ledig, 1986; Hamrick et al., 1991).

Isozyme genetic markers have contributed greatly to investigations of plant mating systems in the past

\footnotetext{
${ }^{*}$ Present address (corresponding author): Department of Biology and Environmental Protection, Pedagogical University, Chodkiewicza 30, PL 85-667 Bydgoszcz 1, Poland.
}

20 years (Clegg, 1980; Brown, 1990; Mitton, 1992). Mating pattern analysis, however, has usually been restricted to estimation of parameters in the mixedmating model, which subdivides all mating events into two classes: self-fertilization and random outcrossing (Fyfe \& Bailey, 1951). The mixed-mating model makes several assumptions, including that the probability of an outcross is independent of maternal genotype, and outcross pollen-pool allele frequencies are homogeneous across maternal parents (Brown et al., 1985; Neale \& Adams, 1985). Evidence in forest trees, however, indicates that these and other assumptions of the mixed-mating model are often violated (Mitton, 1992). In addition, this mating model does not describe patterns of outcross mating within populations, such as the extent to which male mating success is a function of proximity to females or pollen fecundity.

Methods of estimating fertilities of individual males within populations, based on genotypic arrays 
of offspring of individual mothers, were developed by Schoen \& Stewart (1986) and Roeder et al. (1989), but these methods are efficient and unbiased only when populations are small (few potential males) and are isolated from external pollen sources (Adams, 1992). Another approach to analysing mating systems from offspring genotypic arrays is to apply the recently developed neighbourhood model (Adams \& Birkes, 1989, 1991; Adams, 1992). The main advantage of this approach is that it is not necessary to assume that the study population is isolated from external pollen sources. In the neighbourhood model, an arbitrarily specified area around a mother plant is designated its neighbourhood, and the paternity of the mother plant's offspring is partitioned into three sources: selfing, outcrossing within the neighbourhood, and outcrossing outside the neighbourhood.

The neighbourhood model also allows for detailed analyses of mating patterns within neighbourhoods, including the description of various factors influencing male mating success (Adams \& Birkes, 1991; Adams, 1992). The density of pollen dispersed from individual trees drops off rapidly from the source and can be approximated by a negative exponential distribution (Wright, 1953; Wang et al., 1960; Silen, 1962). This suggests that immediate neighbours will account for a large proportion of the offspring of a mother tree. Sorensen (1972) proposed a model accounting for the paternity of offspring of individual mother trees ('pollen samplers') in seed orchard populations. In the absence of background pollination (i.e. from nonorchard sources), this model predicts that most paternity will be from immediate neighbours within the first two to three ranks around a mother tree. This prediction is supported by results in two studies of pollen dispersal from marked males in natural stands of Scots pine, one based on radioactively labelled pollen (Koski, 1970) and the other on isozyme genetic markers (Müller, 1977). In both cases, detection of marked pollen decreased rapidly with increasing distance from the marker male, but the marker male never contributed more than a small percentage $(<11$ per cent) of the marked pollen or offspring detected in any one female receptor. If one assumes that the relationship between male mating success and distance to females is the same for all males and follows the same pattern as the marker male, the proportion of offspring of a mother tree attributable to neighbouring males can be calculated. Based on these assumptions, Koski (1970) estimated that the nearest 25 males around a mother tree were responsible for 60 per cent of matings. We estimate from Müller's
(1977) data that all matings in a second Scots pine stand could be attributed to the nearest 16 males. Isozyme marker data from a third Scots pine stand with much wider spacing among trees, however, indicate that nearby males may be less effective as mates (Yazdani et al., 1989). In this case, the marker male contributed no more than two per cent of the offspring of any receptor female, and the nearest 29 males accounted for only 28 per cent of matings.

The success of neighbouring males in contributing to offspring depends on the proportion of pollen available to the mother tree from males within the neighbourhood relative to sources outside the neighbourhood (Koski, 1970; Sorensen, 1972). One source outside the neighbourhood is other trees within the same stand. The effectiveness of this source depends on the size of the stand, but also on the extent to which intervening trees intercept pollen. The second outside source is pollen from other stands. The amount of this pollen depends on a multitude of factors including the size of the target stand and the degree to which the target stand is isolated from other stands.

The influence of factors other than distance to mother plants on male mating success, such as differential pollen fecundity and pollen dispersal phenology, have been examined only to a limited extent in plants, in general (Levin \& Kerster, 1974; Levin, 1981; Handel, 1983). The few reports in forest trees are restricted almost exclusively to investigations of differential male fertility in conifer seed orchards (Eriksson et al., 1973; Jonsson et al., 1976; Shen et al., 1981; El-Kassaby et al., 1984; Schoen \& Stewart, 1986; El-Kassaby \& Reynolds, 1990; Erickson \& Adams, 1989; Adams \& Birkes, 1991; Adams et al., 1992). These studies show that pollen fecundity and floral phenology can vary widely among orchard clones and can strongly influence mating patterns among neighbouring individuals.

In this paper we use the neighbourhood model and isozyme genetic markers to examine mating patterns in a knobcone pine (Pinus attenuata Lemmon.) stand. Knobcone pine belongs to a group of closed-cone pines, subsection Oocarpae, and is widely dispersed throughout the mountainous region in southern Oregon and northern California (Millar et al., 1988). Cones of knobcone pine are normally borne on the main stem and rarely open on a living tree. Thus, older trees often bear unopened cones from several pollination seasons. Because the cones usually open only after the occurrence of forest fires, the frequency of fire influences the distribution of the species. Knobcone pine usually grows on dry submarginal forest sites, often forming clusters of 
trees which may consist of close relatives, as seed dispersal is probably limited. If mating occurs primarily between near neighbours, clustering of relatives is expected to result in relatively high levels of inbreeding and small effective population size.

Specifically, our objectives were to estimate the proportion of viable offspring resulting from selffertilization, from outcrossing with neighbouring trees, and from outcrossing with distant trees. We were also interested in evaluating the degree to which mating success of neighbouring males is a function of distance and direction to mother trees and pollen fecundity.

\section{Materials and methods}

The sample plot was laid out in an isolated natural stand of knobcone pine located near Sanger Peak in the Siskiyou National Forest, $5 \mathrm{~km}$ south of the Oregon-California border. The stand, $\approx 15$ ha in size, is on a gentle ( 21 per cent) east-facing slope, at about $1280 \mathrm{~m}$ above sea level. Within the stand are isolated individuals of Jeffrey pine (Pinus jeffreyi Grev. \& Balf.), western white pine (Pinus monticola Dougl.) and Douglas-fir (Pseudotsuga menziesii (Mirb.) Franco), and patches of manzanita (Arctostaphylos spp.).

The sample plot, measuring $15 \mathrm{~m}$ in radius, included 79 knobcone pine trees (Fig. 1) which aver-

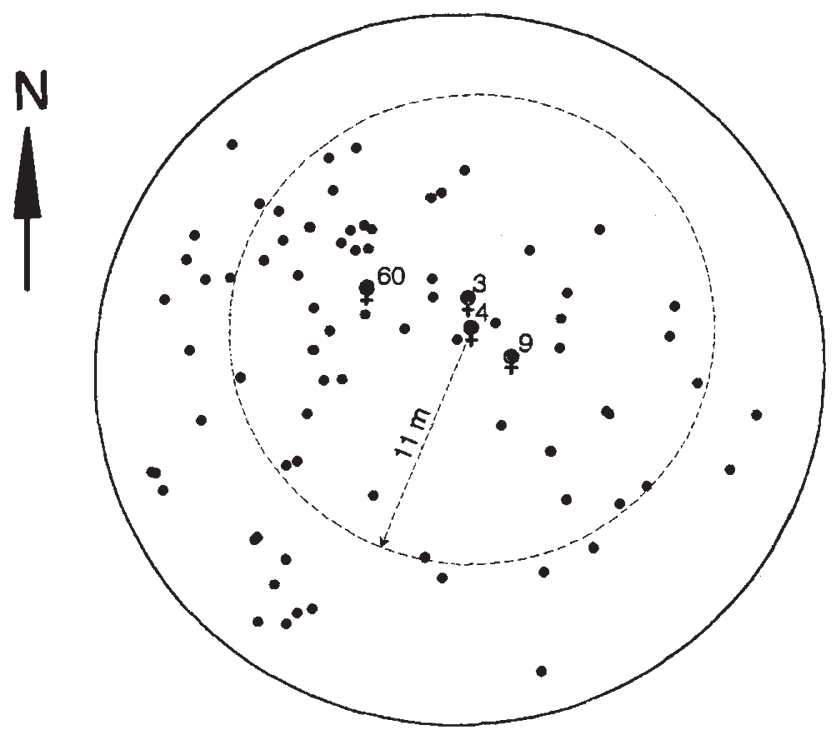

Fig. 1 Location of the 79 knobcone pine trees within the Sanger Peak sample plot. The centrally located mother trees are indicated with their identifying numbers. The designated neighbourhood (11 $\mathrm{m}$ radius) around mother tree 4 is shown as an example. aged $\approx 40-60$ years of age, $6.2 \mathrm{~m}$ in height (range $2.7 \mathrm{~m}$ to $11.0 \mathrm{~m})$ and $9.5 \mathrm{~cm}$ in diameter $(2.5 \mathrm{~cm}$ to $29.0 \mathrm{~cm})$ at breast height $(1.37 \mathrm{~m})$. Positions of all trees within the plot were mapped. Although flowering could not be observed directly at the time of plot establishment and cone collection (October, 1992), the trees within the plot were examined closely for evidence of pollen production in recent years. Fourteen, generally smaller trees, lacked twig scars from past male strobili and had none (12 trees) or only a few female cones. These 14 trees were dropped from the study, leaving 65 trees within the plot considered as potential fathers in the mating analyses.

Seed samples were collected from three main sources: (1) specified mother trees in the centre of the sample plot; (2) all remaining trees with cones in the plot; and (3) trees representing pollen sources outside the plot. Four individuals were designated as mother trees for sampling purposes, around each of which an $11 \mathrm{~m}$ radius circular neighbourhood was considered. This rather limited neighbourhood area was chosen for three reasons. (1) The number of potential males among these neighbours was large, ranging from 41 to 48 (mean 44.25). (2) Based on previous studies, we had a reasonable expectation that a relatively large proportion of matings would be from males within neighbourhoods of this size. If this were not true, then at least we would learn this and could conclude that local males have relatively little impact on outcross mating patterns within this knobcone pine population. (3) There are also practical limitations to the size of neighbourhoods that can be accommodated. This is because as neighbourhood size increases, so does the number of trees that have to be individually genotyped and mapped. In addition, the larger the number of males within neighbourhoods, the greater the difficulty there is in discriminating genetically between pollen gametes derived from males within neighbourhoods vs. those originating from outside sources, including other stands (Adams \& Birkes, 1989, 1991; Adams, 1992).

Ten cones varying in age between 2 and 5 years were collected from the top of the crown of each mother tree and one or two cones were sampled from all remaining cone-bearing trees in the plot. In order to characterize the genetic composition of pollen sources outside the sample plot, cones from 56 trees scattered in all directions were sampled. This sampling attempted to reflect the density and distribution of knobcone pine trees in the local area and included trees up to $75 \mathrm{~m}$ north, $200 \mathrm{~m}$ south, $150 \mathrm{~m}$ east, and $75 \mathrm{~m}$ west of the sample plot.

Three types of tissue were subjected to electrophoresis. First, multilocus diploid genotypes of all 
cone-bearing trees within the sample plot and the 56 trees sampled outside the plot were inferred by assaying at least eight megagametophytes $(1 n)$ per tree. With this sample size, the probability of misidentifying the genotype of a tree at any one locus is less than $(1 / 2)^{7}=0.008$ (Morris \& Spieth, 1978). Secondly, genotypes of potential fathers within the study plot which produced no cones (two trees, including one cone-bearing individual with only empty seeds) were determined from dormant buds sampled in March 1993. Finally, both embryos (2n) and megagametophytes were assayed in seeds in order to determine the genotypes of pollen gametes for mating pattern analysis. Because the ovule is genetically identical to the megagametophyte, the genotypes of pollen gametes can be inferred from embryos once the genotypes of the corresponding megagametophytes are known (Adams, 1983). Ten seeds (pollen gametes) from each of 26 trees randomly chosen from cone-bearing trees within the sample plot (including mother trees) were sampled to estimate a population-wide outcrossing rate (mixed-mating model), and 220 seeds from each of the four designated mother trees were sampled for the neighbourhood mating-pattern analysis.

Electrophoretic techniques were similar to those described in Conkle et al. (1982). The extraction buffer of Mitton et al. (1979) was used when crushing buds. Eleven polymorphic loci (Aco, Adh2, Aat1, Fest, Idh, Lap1, Lap2, Mnr3, Pgm1, 6-Pgd and Pgi2) were chosen for analysis because they could be clearly distinguished in all tissues. Banding patterns, verification of their Mendelian inheritance and linkage relationships have been reported previously (Strauss \& Conkle, 1986). Several pairs of loci appear to be linked, but only weakly (recombination frequencies >0.18). Only Aat1 and Pgi2 are closely linked, with a recombination frequency of 0.08 .

\section{Statistical procedures}

Statistical analyses of mating patterns were performed using both the mixed-mating and the neighbourhood models. In the mixed-mating model, the multilocus estimation of mother-tree (i.e. pollen gamete data for four mother trees pooled) and population-wide outcrossing rates were based on the maximum-likelihood procedures of Ritland \& El-Kassaby (1985), using the computer program developed for conifers.

The neighbourhood model was applied following Adams \& Birkes $(1989,1991)$. This model assumes that pollen successful in fertilizing viable offspring of a mother tree comes from three sources: self-fertili- zation (with probability $s$ ), migrant pollen from outside the neighbourhood (probability $m$ ), and cross-fertilization with males within the neighbourhood (probability $1-m-s$ ), with relative mating success (i.e. fertility) of the $j$ th outcross male in the neighbourhood equal to $\phi_{j}$. The probability of observing multilocus genotype $g_{i}$ in the pollen gametes of offspring from the mother tree is

$$
\begin{aligned}
P\left(g_{i}\right)= & s P\left(g_{i} \mid M\right)+(1-m-s) \sum_{j=1}^{r} \phi_{j} P\left(g_{i} \mid F_{j}\right) \\
& +m P\left(g_{i} \mid B\right),
\end{aligned}
$$

where $P\left(g_{i} \mid M\right)$ is the transition probability (Adams $\&$ Birkes, 1991) that the mother tree produces gametes with genotype $g_{i}, P\left(g_{i} \mid F_{j}\right)$ is the transition probability for the $j$ th (out of $r$ ) outcross male in the neighbourhood, and $P(g \mid B)$ is the probability that pollen gametes from sources outside the neighbourhood (background) have genotype $g_{i}$. The mating success (i.e. fertility) of each outcross male in the neighbourhood $\left(\phi_{j}\right)$ is assumed to follow an exponential relationship,

$$
\phi_{j}=\frac{e^{u_{j}}}{\sum_{k=1}^{r} e^{u_{k}}},
$$

where $u_{j}$ is a linear function of one or more factors influencing mating success. We investigated three factors expected to influence mating success of potential males within neighbourhoods: distance and direction to the mother tree and tree height. Tree height may be considered a surrogate for pollen fecundity because the magnitude of male and female flowering is positively correlated with tree size (Eriksson et al., 1973). Indeed, the linear correlation between tree size and number of female cones (cone scores) was 0.767 for trees within the sample plot. When all three factors are considered simultaneously,

$$
\phi_{j}=\frac{e^{\beta d_{j}+\gamma h_{j}+\delta \cos \left(\alpha_{0}-\alpha_{j}\right)}}{\sum_{k=1}^{r} e^{\beta d_{k}+\gamma h_{k}+\delta \cos \left(\alpha_{0}-\alpha_{k}\right)}},
$$

where $d_{j}$ and $h_{j}$ indicate distance $(\mathrm{m})$ from the mother tree and height $(\mathrm{m})$ of the $j$ th male in the neighbourhood, respectively, and $\alpha_{0}-\alpha_{j}$ is the angle between the presumed prevailing direction of effective pollen dispersal and the location of the $j$ th male. $\beta, \gamma$ and $\delta$ are the parameters describing the effects of each of the respective factors. 
The exponential function (eqns 2 and 3 ) was chosen because it provides a great deal of flexibility to approximate relationships that we might reasonably expect between $\phi_{j}$ and each factor. Parameter values can be positive or negative. When the parameter describing the relationship with any one factor is positive, mating success increases in a more or less exponential fashion with increasing value of that factor [e.g. as would be expected with pollen fecundity (tree height)]. When the parameter is negative, mating success decreases with increasing value of the factor (e.g. as would be expected for distance from the mother tree). The larger the value of the parameter, the steeper the increase or decrease relative to change in the factor. When the parameter has a value of zero, $\phi_{j}$ is unrelated to the factor (Adams \& Birkes, 1991; Adams, 1992).

The most complete neighbourhood model we investigated included parameters for all three factors influencing mating success of potential males within neighbourhoods. This model had five parameters in total: $s, m, \beta, \gamma, \delta$ (see eqns 1 and 3 ). We also investigated various subsets of this 'full' model (i.e. with fewer parameters) and various pairwise interactions between the three factors influencing mating success. For example, when $d_{j}, h_{j}$ and their interaction is of interest, the mating success function (eqn 2) becomes

$$
\phi_{j}=\frac{e^{\beta d_{j}+\gamma h_{j}+\varepsilon\left(d, h_{j}\right)}}{\sum_{k=1}^{r} e^{\beta d_{k}+\gamma h_{k}+\varepsilon\left(d_{k} h_{k}\right)}},
$$

where $\varepsilon$ is the parameter describing the interaction effect.

Parameters in the various neighbourhood models were estimated by fitting the models to multilocus pollen gametic arrays in the offspring of individual mother trees using maximum likelihood (ML) methods (Rao, 1970). Parameters were estimated for each of the four mother trees separately, as well as for data pooled over all mother trees. The likelihood function for a sample of pollen gametes from mother tree $l$ is

$L_{l}(s, m, \beta, \gamma, \delta)=\prod_{i=1}^{n} P\left(g_{i}\right)$,

and the joint likelihood for a combined sample over all mothers is

$L(s, m, \beta, \gamma, \delta)=\prod_{l=1}^{4} L_{i}$.
Parameter estimates were obtained numerically by using the method of scoring (Rao, 1970). A computer program for this purpose, written in BASIC (TURBo BASIC v. 1.0, Borland International, Inc., 1987), can be obtained by sending a blank diskette to the corresponding author.

Model selection was accomplished by first fitting the simplest model, containing only the effect of background pollination (parameter $m$ ). Parameters were then added to the model if the likelihood ratio test (Rao, 1973) showed that they were significantly $(P<0.05)$ different from zero. This procedure resulted in several candidate models, with different combinations of parameters. The model with the greatest likelihood (i.e. smallest negative log-likelihood) was declared the best-fitting model. To estimate the directionality parameter $(\delta)$, loglikelihoods were calculated for different angles of the presumed direction of prevailing pollen dispersal $\left(\alpha_{0}\right)$. The value of $\delta$ corresponding to $\hat{\alpha}_{0}$ with the highest likelihood was $\hat{\delta}$.

Given estimates of the mating success parameters in the best-fitting model, fertilities of individual males within a neighbourhood can be derived (eqn 2). The effective number of males in the neighbourhood siring the offspring of individual mother trees can be estimated as

$\hat{N}_{\mathrm{e}}=1 / \sum_{j=1}^{r} \hat{\phi}_{j}^{2}$.

The effective number of males is the equivalent number of male parents in an idealized situation where all males in the neighbourhood have equal fertilities (Sect. 7.6.2, Crow \& Kimura, 1970). Estimated fertilities were also used to calculate mean distances between mother trees and their outcrossing mates within neighbourhoods,

$\hat{\mu}_{d}=\sum_{j=1}^{r} d_{j} \hat{\phi}_{j}$.

\section{Results}

In general, chi-square heterogeneity tests (Rao, 1973) indicated that parameter estimates were homogeneous $(P>0.05)$ over individual mother trees. Thus, we present only the results obtained by fitting the neighbourhood model to the data sets of all four mother trees simultaneously. Log-likelihoods decreased significantly with each addition of the model parameters, such that the best-fitting model included parameters for selfing $(s)$, background pollination $(m)$, and all three parameters $(\beta, \gamma, \delta)$ 
relating mating success of males in the neighbourhood to factors expected to influence mating success (model 9, Table 1). None of the pairwise interactions between the mating success parameters was significant (results not shown).

The mean outcrossing rate $(\hat{t})$ estimated using the neighbourhood model $(1-\hat{s}=0.968$, Table 1$)$ was nearly identical to the estimate obtained for the pooled mother-tree data using the mixed-mating model $[\hat{t}=0.964(\mathrm{SE}=0.010)]$. Both estimates based on the four mother trees, however, were slightly, but not significantly $(P>0.09$, based on $z$-test), greater than the population-wide outcrossing rate $[\hat{t}=0.923$ (0.022)] obtained by applying the mixed-mating model to pollen gametes sampled from 26 trees within the study plot.

Background pollination $(\hat{m})$ accounted for more than 50 per cent of pollen gametes, indicating that a considerable amount of effective pollen came from sources outside the neighbourhoods (Table 1). Only
41.3 per cent $(1-\hat{s}-\hat{m}$; Table 1$)$ of the matings resulted from outcrosses with neighbouring males.

Mating success of males within neighbourhoods decreased with increasing distance from mother trees $(\hat{\beta}=-0.188)$, but increased with increasing tree size $(\hat{\gamma}=0.369)$ (Table 1$)$. The effect of tree size on mating success, however, appears to decrease with increasing distance of males from mother trees (Fig. 2). This is because increasing tree height and distance from mother trees have opposing influences on mating success, such that when an individual male is far away, it has little probability of mating with the mother tree, regardless of its size.

The prevailing direction of effective pollen dispersal within neighbourhoods $\left(\alpha_{0}\right)$ that gave the best fit of the model was 91 degrees from north (nearly due east). The corresponding value of the directionality parameter $(\delta)$ was estimated to be 0.560 (Table 1 ). When all other factors are equal, males due east of the mother trees are estimated to have had the

Table 1 Maximum likelihood estimates of parameters in different neighbourhood models applied to pollen gamete data pooled over four mother trees of knobcone pine

\begin{tabular}{|c|c|c|c|c|c|c|}
\hline \multirow[b]{2}{*}{ Model } & \multicolumn{5}{|c|}{ Parameter estimates $\dagger$ (SE) } & \multirow[b]{2}{*}{$\log -L \neq$} \\
\hline & $s$ & $m$ & $\beta$ & $\gamma$ & $\delta$ & \\
\hline 1 & - & $\begin{array}{c}0.611 \\
(0.030)\end{array}$ & - & - & - & -4478.04 \\
\hline 2 & $\begin{array}{c}0.029 \\
(0.010)\end{array}$ & $\begin{array}{c}0.594 \\
(0.031)\end{array}$ & - & - & - & -4470.58 \\
\hline 3 & $\begin{array}{c}0.032 \\
(0.010)\end{array}$ & $\begin{array}{c}0.586 \\
(0.030)\end{array}$ & $\begin{array}{r}-0.190 \\
(0.041)\end{array}$ & - & - & -4460.13 \\
\hline 4 & $\begin{array}{c}0.028 \\
(0.010)\end{array}$ & $\begin{array}{c}0.592 \\
(0.031)\end{array}$ & - & $\begin{array}{c}0.331 \\
(0.064)\end{array}$ & - & -4458.19 \\
\hline 5 & $\begin{array}{c}0.030 \\
(0.010)\end{array}$ & $\begin{array}{c}0.579 \\
(0.031)\end{array}$ & - & - & $\begin{array}{c}0.592 \\
(0.156)\end{array}$ & -4463.81 \\
\hline 6 & $\begin{array}{c}0.030 \\
(0.010)\end{array}$ & $\begin{array}{c}0.570 \\
(0.030)\end{array}$ & $\begin{array}{c}-0.226 \\
(0.038)\end{array}$ & $\begin{array}{c}0.381 \\
(0.062)\end{array}$ & - & -4441.06 \\
\hline 7 & $\begin{array}{c}0.033 \\
(0.010)\end{array}$ & $\begin{array}{c}0.575 \\
(0.030)\end{array}$ & $\begin{array}{r}-0.180 \\
(0.040)\end{array}$ & - & $\begin{array}{c}0.526 \\
(0.145)\end{array}$ & -4453.64 \\
\hline 8 & $\begin{array}{c}0.030 \\
(0.010)\end{array}$ & $\begin{array}{c}0.564 \\
(0.031)\end{array}$ & - & $\begin{array}{c}0.362 \\
(0.059)\end{array}$ & $\begin{array}{c}0.799 \\
(0.160)\end{array}$ & -4446.77 \\
\hline 9 & $\begin{array}{c}0.032 \\
(0.010)\end{array}$ & $\begin{array}{c}0.555 \\
(0.031)\end{array}$ & $\begin{array}{c}-0.188 \\
(0.038)\end{array}$ & $\begin{array}{c}0.369 \\
(0.059)\end{array}$ & $\begin{array}{c}0.560 \\
(0.150)\end{array}$ & -4434.07 \\
\hline
\end{tabular}

$\dagger$ Estimates are given only for those parameters included in the model. A dash (一) indicates that the parameter was not in the model. Model parameters are as follows: $s$ and $m$ are proportions of pollen gametes from self-fertilization and gene flow from outside neighbourhoods, respectively; and, $\beta, \gamma$, and $\delta$ are parameters relating mating success of males within neighbourhoods to distance from the mother tree, tree height, and direction to the mother tree, respectively. $\ddagger$ Natural logarithm of the likelihood function. The least negative log-likelihoods have the highest likelihood values. 


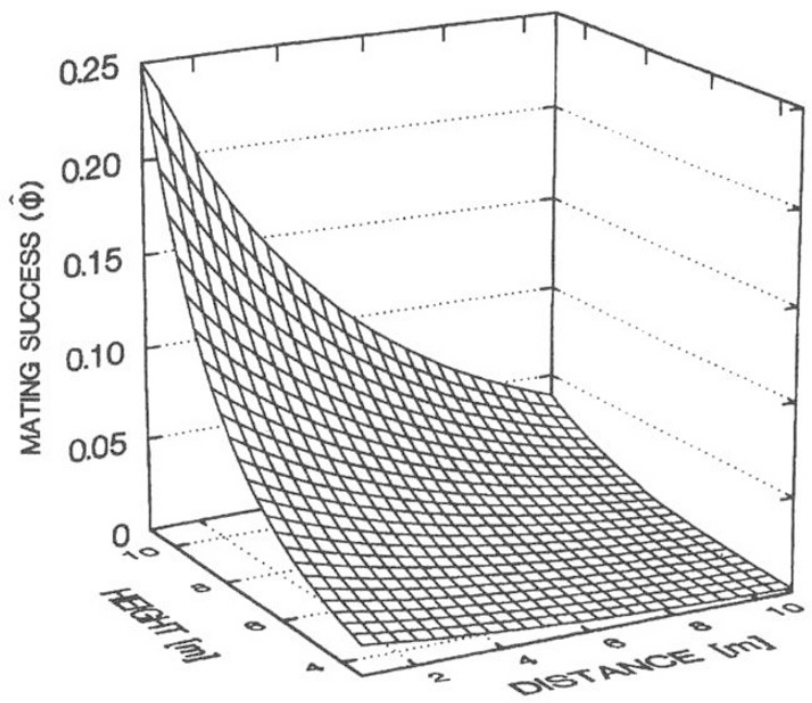

Fig. 2 The joint effects of distance from mother tree and tree height on relative mating success $(\hat{\phi})$ of males within neighbourhoods of knobcone pines when the effect of directionality of males is ignored. The plot is based on $\hat{\phi}$ values over all four neighbourhoods and is specific for the observed distribution of distances and heights of male trees in these neighbourhoods.

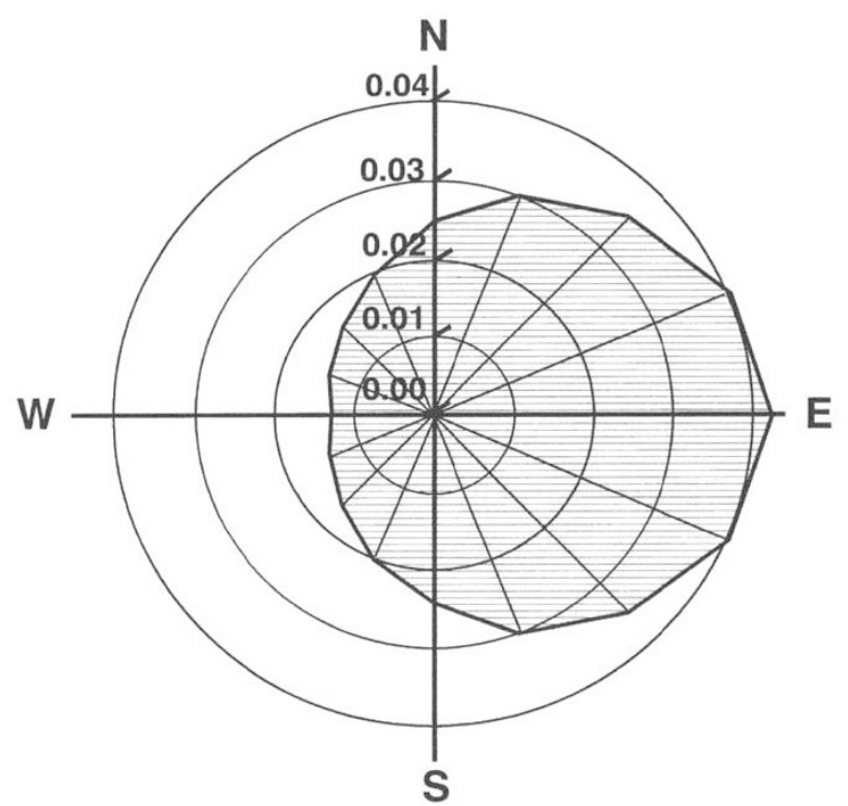

Fig. 3 Relationship between relative mating success $(\hat{\phi})$ of males within neighbourhoods of knobcone pines and their location relative to that of the mother tree (i.e. direction to the mother trees) when the effects of distance to mother tree and tree height are ignored. The concentric rings represent values of $(\hat{\phi})$ as indicated. The plot is based on $\hat{\phi}$ values over all four neighbourhoods and is specific for the observed distribution of relative locations of male trees in these neighbourhoods. highest relative mating success, whereas males in progressively more westerly directions had lower mating success (Fig. 3). Males due west of the mother trees are only about one-third as effective in mating as those due east.

The mean effective number of outcross males within each neighbourhood is estimated to be 10.75 , which is about one-quarter of the mean number of potential males (44.25). The mean distance between mother trees and their outcross mates within neighbourhoods (i.e. mean effective pollen dispersal within neighbourhoods) was $5.34 \mathrm{~m}$, whereas the average distance between mother trees and potential outcross males within neighbourhoods was $6.82 \mathrm{~m}$.

\section{Discussion}

\section{Outcrossing vs. selfing}

The high rate of outcrossing observed in knobcone pine is consistent with estimates for other pine species (Furnier \& Adams, 1986; Perry \& Dancik, 1986; El-Kassaby et al., 1987; Muona \& Harju, 1989; Burczyk, 1991), and for conifers in general (Adams \& Birkes, 1991; Mitton, 1992). Only in a few conifers have $t$ estimates less than 80-90 per cent been reported (Perry \& Knowles, 1990; Xie et al., 1991; El-Kassaby et al., 1994).

Clustering of mature female cones along the main stem is expected to hamper seed dispersal after fires, resulting in spatial clustering of relatives (family structure) in regenerated stands. Mating among neighbouring trees therefore may produce inbred offspring, some of which may be genetically indistinguishable from selfs, causing a downward bias in estimates of outcrossing. The neighbourhood analysis of mating patterns in this study, however, indicates that the majority of mating was not between neighbouring individuals.

\section{Gene flow from outside of neighbourhoods}

It is debatable whether the estimated amount of gene flow into the neighbourhoods (56 per cent) should be considered large or small. On the one hand, conifer pollen is known to be dispersed, in mass, for considerable distances (Lanner, 1966; Levin \& Kerster, 1974). In addition, estimates of gene flow (pollen contamination) into artificial seed production stands (i.e. seed orchards) often exceed 40 per cent (Adams \& Birkes, 1991; Adams et al., 1992), even when the stands are isolated by up to $100 \mathrm{~m}$ or so from natural populations of the same species. Given the above and the small size of the 
neighbourhoods, gene flow of the magnitude observed in this study does not seem high, especially when it is considered that pollen from surrounding trees in the same stand, as well as from other stands, were sources of background pollen.

On the other hand, knobcone pine has a more or less patchy distribution in the area of the study. Furthermore, the knobcone pine population we sampled is located on the top of a ridge at about $1280 \mathrm{~m}$ elevation and probably flowered somewhat later than warmer sites at lower elevations. Thus, the study stand may have been somewhat isolated, both spatially and phenologically from other stands in the region. These factors tend to limit the impact of gene flow from other stands. Thus, it is entirely possible that most of the background pollination observed in this study originated from trees in the same stand, but from outside the small designated neighbourhoods of $11 \mathrm{~m}$ radius.

\section{Patterns of effective pollen dispersal within neighbourhoods}

In our study, distance and direction to the mother, and height of males, all appear significantly to influence patterns of mating among neighbouring trees. Although mating within neighbourhoods accounted for only 41 per cent of the offspring, mating success decreased rapidly with distance from mother trees (at least for taller trees, Fig. 2), which agrees with previous findings based on the rare-marker approach.

The height of male trees may have a two-fold effect on their mating success: taller trees not only produce more pollen (Eriksson et al., 1973), but disperse it over larger distances (Di-Giovanni \& Kevan, 1991). Thus, the significant effect of tree height on mating patterns is not unexpected. Although tree height is only a surrogate for relative pollen fecundity, the results suggest that fecundity differences among males are as important in determining male fertility in natural stands, as they are in seed orchards.

The influence of direction on effective pollen dispersal has rarely been studied in forest tree populations. One example is the work of Shen et al. (1981). They found that capture of rare marker alleles by female receptor trees was greatest downwind of the male marker in a Scots pine seed orchard. We also found directionality to be important in influencing mating success (Fig. 3), but cannot relate the patterns to prevailing wind direction. The only information we have on wind direction comes from a meteorological station on the top of a mountain (Crazy Peak, $1580 \mathrm{~m}$ ), $4.6 \mathrm{~km}$ southeast of the study plot. Prevailing day-time winds at this station in June, the usual pollination period for knobcone pine in this region, is from the south or south-west (data from USDA, Forest Service, Siskiyou National Forest). Our results, however, suggest that mating success is greatest for males east of the mother trees. Perhaps the local topography and vegetation on or near the study plot modified the prevailing wind direction. To know for sure, wind patterns during the pollination season would have to be monitored on the study site itself.

Effective population sizes are generally assumed to be large in natural populations of forest trees (Koski, 1970). We estimated the effective number of outcross males within neighbourhoods mating with each mother tree to be 10.75 , about one-quarter of the potential males. Given that more than 50 per cent of the outcross pollen came from trees outside the neighbourhoods (Table 1), and that probably a large number of males contribute to this background pollen source, the actual effective number of males mating with each mother tree is expected to be relatively large. The effective number of males mating with each female considering all pollen sources can be estimated in a way similar to eqn 7 as

$N_{\mathrm{e}}=1 /\left[s^{2}+(1-m-s)^{2} \Sigma \phi_{j}^{2}+m^{2} \Sigma \rho_{k}^{2}\right]$,

where $\rho_{k}$ is the relative fertility of the $k$ th background male (i.e. fertility of the $k$ th male relative to other males in the background) and $\Sigma \rho_{k}=1$. If we assume that the number of males mating with the mother tree from background stands is large and each $\rho_{k}$ small, $m^{2} \Sigma \rho_{k}^{2}$ is near zero. Thus, the overall $N_{\mathrm{e}}$ for individual mother trees in the knobcone pine stand can be approximated as

$$
\begin{aligned}
N_{\mathrm{e}} & =1 /\left[s^{2}+(1-m-s)^{2} \Sigma \phi_{j}^{2}\right] \\
& =1 /\left[(0.032)^{2}+(0.413)^{2}(1 / 10.75)\right]=59.2 .
\end{aligned}
$$

At first sight, the decreasing mating success of individual males with increasing distance from mother trees, and the large proportion of offspring resulting from distant pollen sources (gene flow) may seem contradictory (Adams, 1992; Wheeler et al., 1993). Although pollen dispersal from individual trees follows a leptokurtic distribution (Levin \& Kerster, 1974), the long-distance dispersed pollen (tails of the distribution) summed over many distant trees can be considerable. Thus, if fertilization success is proportional to the relative amount of pollen contributed to the pollen cloud around a mother tree, distant pollen sources might account for the majority of offspring. 
The available data are insufficient to draw general conclusions about outcross patterns of mating in forest trees. These patterns need to be investigated in more species and for a wider variety of breeding systems. The influence of ecological factors in addition to distance between mates, such as floral phenology, relative pollen fecundity, and stand age, density and structure, need to be understood. Because the neighbourhood model approach can incorporate a variety of these factors, it is a promising tool for further studies of mating patterns in plant populations.

\section{Acknowledgements}

This research was done while J. Burczyk and J. Shimizu were visiting scientists in the Department of Forest Science at Oregon State University. We thank the Fulbright Program for a Visiting Scholar grant to J. Burczyk and to EMBRAPA and the Brazilian Council for Science and Technology (CNPq) for providing a fellowship to J. Shimizu. The USDA, Forest Service, Siskiyou National Forest, assisted in locating a suitable knobcone pine stand and supplied weather data. Dr David Birkes, Department of Statistics at OSU, was helpful in developing the estimation procedures. This is paper number 3090 of the Forest Research Laboratory, Oregon State University.

\section{References}

ADAMS, w. T. 1983. Application of isozymes in tree breeding. In: Tanksley, S. D. and Orton, T. J. (eds) Isozymes in Plant Genetics and Breeding, Part A, pp. 381-400. Elsevier Science Publ., Amsterdam.

ADAMS, w. T. 1992. Gene dispersal within forest tree populations. New Forests, 6, 217-240.

ADAMS, w. T. AND BIRKES, D. s. 1989. Mating patterns in seed orchards. In: Proceedings of the 20th Southern Forest Tree Improvement Conference, June 26-30, 1989, pp. 75-86. Charleston, SC.

ADAMS, W. T. AND BIRKES, D. S. 1991. Estimating mating patterns in forest tree populations. In: Fineschi, S., Malvolti, M. E., Cannata, F. and Hattemer, H. H. (eds) Biochemical Markers in the Population Genetics of Forest Trees, pp. 157-172. SPB Academic Publishing, The Hague, Netherlands.

ADAMS, W. T., BIRKES, D. S. AND ERICKSON, V. J. 1992. Using genetic markers to measure gene flow and pollen dispersal in forest tree seed orchards. In: Wyatt, R. (ed.) Ecology and Evolution of Plant Reproduction, pp. 37-61. Chapman and Hall, New York.

BROWN, A. H. D. 1990. Genetic characterization of plant mating systems. In: Brown, A. H. D., Clegg, M. T., Kahler, A. L. and Weir, B. S. (eds) Plant Population
Genetics, Breeding and Genetic Resources, pp. 145-162. Sinauer Associates, Sunderland, MA.

BROWN, A. H. D., BARRETT, S. C. H. AND MORAN, G. F. 1985. Mating system estimation in forest trees: models, methods, and meanings. In: Gregorius, H.-R. (ed) Population Genetics in Forestry, pp. 32-49. SpringerVerlag, Berlin.

BURCZYK, J. 1991. The mating system in a Scots pine clonal seed orchard in Poland. Ann. Sci. For, 48, 443-451.

CLEGG, M. T. 1980. Measuring plant mating systems. Bioscience, 30, 814--818.

CONKLE, M. T., HODGSKISS, P. D., NUNNALLY, L. B. AND HUNTER, S. C. 1982. Starch Gel Electrophoresis of Conifer Seeds: a Laboratory Manual. USDA Forest Service General Technical Report, PSW-64. 18 pp.

Crow, J. F. AND KIMURa, M. 1970. An Introduction to Population Genetics Theory. Harper and Row, New York.

Dl-GlovanNl, F. AND KEVAN, P. G. 1991. Factors affecting pollen dynamics and its importance to pollen contamination: a review. Can. J. Forest Res., 21, 1155-1170.

EL-KASSABY, Y. A. AND REYNOLDS, s. 1990. Reproductive phenology, parental balance, and supplemental mass pollination in a Sitka spruce seed orchard. Forest Ecol. Manag., 31, 45-54.

EL-KASSABY, Y. A., FASHLER, A. M. K. AND SZIKLAl, O. 1984. Reproductive phenology and its impact on genetically improved seed production in a Douglas-fir seed orchard. Silvae Genet., 33, 120-125.

EL-KASSABY, Y. A., MEAGHER, M. D., PARKINSON, J. AND PORTLOCK, F. T. 1987. Allozyme inheritance, heterozygosity and outcrossing rate among Pinus monticola near Ladysmith, British Columbia. Heredity, 58, 173-181.

EL-KASSABY, Y. A., RUSSELl, J. AND RITLAND, K. 1994. Mixed mating in an experimental population of western red cedar, Thuja plicata. J. Hered., 85, 228-231.

ERICKSON, v. J. AND ADAMS, w. T. 1989. Mating success in a coastal Douglas-fir seed orchard as affected by distance and floral phenology. Can. J. Forest Res., 19, 1248-1255.

ERIKSSON, G., JONSSON, A. AND LINDGREN, D. 1973. Flowering in a clone trial of Picea abies Karst. Stud. Forest. Suec, 110, 1-45.

FURNIER, G. R. AND ADAMS, w. T. 1986. Mating system in natural populations of Jeffrey pine. Am. J. Bot., 73, 1009-1015.

FYFE, J. L. AND BAILEY, N. T. J. 1951. Plant breeding studies in leguminous forage crops. 1. Natural crossbreeding in winter beans. J. Agric. Sci., 41, 371-378.

HAMRICK, J. L. 1989. Isozymes and the analysis of genetic structure in plant populations. In: Soltis, D. E. and Soltis, P. S. (eds) Isozymes in Plant Biology, pp. 78-105. Dioscorides Press, Portland, OR.

HAMRICK, J. L., GODT, M. J. W., MURAWSK1, D. A. AND LOVELESS, M. D. 1991. Correlations between species traits and allozyme diversity: implications for conservation biology. In: Falk, D. A. and Holsinger, K. E. (eds) Genetics and Conservation of Rare Plants, pp. 75-86. Oxford University Press, New York. 
HANDEl, s. N. 1983. Pollination ecology, plant population structure, and gene flow. In: Real, L. (ed.) Pollination Biology, pp. 163-211. Academic Press, New York.

JONSSON, A., EKBERG, I. AND ERIKSSON, G. 1976. Flowering in a seed orchard of Pinus sylvestris L. Stud. Forest. Suec, , 135, 1-38.

KoskI, v. 1970. A study of pollen dispersal as a mechanism of gene flow in conifers. Commun. Inst. Forest. Fenn., 70.4., 1-78.

LANNER, R. M. 1966. Needed: a new approach to the study of pollen dispersion. Silvae Genet., 15, 50-52.

LEDIG, F. T. 1986. Heterozygosity, heterosis, and fitness in outbreeding plants. In: Soulé, M. E. (ed.) Conservation Biology: the Science of Scarcity and Diversity, pp. 77-104. Sinauer, Sunderland, MA.

LEVIN, D. A. 1981. Dispersal versus gene flow in plants. Ann. Mo. Bot. Gard., 68, 233-253.

LEVIN, D. A. AND KERSTER, H. W. 1974. Gene flow in seed plants. In: Dobzhansky, T., Hecht, M. T. and Steere, W. C. (eds) Evolutionary Biology, vol. 7, pp. 139-220. Plenum Press, New York.

MILLAR, C. I., STRAUSS, S. H., CONKLE, M. T. AND WESTFALL, R. D. 1988. Allozyme differentiation and biosystematics of the Californian closed-cone pines (Pinus subsect. Oocarpae). Syst. Bot., 13, 351-370.

MITTON, J. B. 1992. The dynamic mating systems of conifers. New Forests, 6, 197-216.

MITTON, J. B., LINHART, Y. B., STURGEON, K. B. AND HAMRICK, J. L. 1979. Allozyme polymorphisms detected in mature needle tissue of Ponderosa pine. J. Hered, 70, 86-89.

MORRIS, R. W. AND SPIETH, P. T. 1978. Sampling strategies for using female gametophytes to estimate heterozygosity in conifers. Theor. Appl. Genet., 51, 217-222.

MÜlleR, G. 1977. Cross-fertilization in a conifer stand inferred from enzyme gene-markers in seeds. Silvae Genet., 26, 223-226.

MUONA, O. AND HARJU, A. 1989. Effective population sizes, genetic variability, and mating system in natural stands and seed orchards of Pinus sylvestris. Silvae Genet., 38, 221-228.

NEALE, D. B. AND ADAMS, w. T. 1985. The mating system in natural and shelterwood stands of Douglas-fir. Theor. Appl. Genet., 71, 201-207.

PERRY, D. J. AND DANC1K, B. P. 1986. Mating system dynamics of lodgepole pine in Alberta, Canada. Silvae Genet., 35, 190-195.
PERRY, D. J. AND KNOWLES, P. 1990. Evidence of high selffertilization in natural populations of eastern white cedar (Thuja occidentalis). Can. J. Bot., 68, 663-668.

RAO, C. R. 1970. Advanced Statistical Methods in Biometric Research. Hafner Publ. Co., Darien, CT.

RAO, C. R. 1973. Linear Statistical Inference and its Applications, 2nd edn. John Wiley and Sons, New York.

RITLAND, K. AND EL-KASSABY, Y. A. 1985. The nature of inbreeding in a seed orchard of Douglas-fir as shown by an efficient multilocus model. Theor. Appl, Genet., 71, 375-384.

ROEDER, K., DEVliN, B. AND LINDSAY, B. G. 1989. Application of maximum likelihood methods to population genetic data for the estimation of individual fertilities. Biometrics, 45, 363-379.

SCHOEN, D. J. AND STEWART, s. C. 1986. Variation in male reproductive investment and male reproductive success in white spruce. Evolution, 40, 1109-1120.

SHEN, H.-H., RUDIN, D. AND LINDGREN, D. 1981. Study of pollination pattern in a Scots pine seed orchard by means of isozyme analysis. Silvae Genet., 30, 7-15.

SILEN, R. R. 1962 Pollen dispersal considerations for Douglas-fir. J. Forestry, 60, 790-795.

SORENSEN, F. C. 1972. The seed orchard tree as a pollen sampler: a model and example. USDA Forest Service Research Note PNW-175, 11 pp.

STRAuSs, S. H. AND CONKLE, M. T. 1986. Segregation, linkage, and diversity of allozymes in knobcone pine. Theor. Appl. Genet., 72, 483-493.

WANG, C.-W., PERry, T. O. AND JOHNSON, A. G. 1960. Pollen dispersion of slash pine (Pinus elliotii Engelm.) with special reference to seed orchard management. Silvae Genet., 4, 78-86.

WHEELER, N. C., ADAMS, W. T. AND HAMRICK, J. L. 1993. Pollen distribution in wind-pollinated seed orchards. In: Bramlett, D. L., Askew, G. R., Blush, T. D., Bridgwater, F. E. and Jett, J. B. (eds) Advances in Pollen Management, pp. 25-31. USDA Forest Service Agricultural Handbook 698.

WRight, J. w. 1953. Pollen dispersion studies: some practical applications. J. Forestry, 51, 114-118.

XIE, C. Y., DANCIK, B. P. AND YEH, F. C. 1991. The mating system in natural populations of Thuja orientalis. Can. J. Forest Res., 21, 333-339.

YAZDAN1, R., LINDGREN, D. AND STEWART, s. 1989. Gene dispersion within a population of Pinus sylvestris. Scand. J. Forest Res., 4, 295-306. 